\title{
BETWEEN TRANSCENDENCE AND IMMANENCE: THE CONSTRUCTION OF FAZLUR RAHMAN'S THOUGHTS ABOUT GOD
}

\author{
Amril $^{1 *}$, Endrika Widdia Putri ${ }^{1}$ \\ ${ }^{1}$ Universitas Islam Negeri (UIN) Imam Bonjol Padang \\ *Corresponding author: amrilmag@uinib.ac.id \\ (c) (1) (2) \\ (C)2021 by the authors. Submitted for possible open access publication under the terms and conditions \\ of the Creative Commons Attribution-ShareAlike 4.0 International License (CC-BY-SA) \\ license (https://creativecommons.org/licenses/by-sa/4.0/) \\ doi DOI: http://dx.doi.org/10.30983/fuaduna.v5i2.4968
}

Received: November 07, $2021 \quad$ Revised: December 20, $2021 \quad$ Published: December 31, 2021

\begin{abstract}
This article analyzes the construction of Fazlur Rahman's thoughts about God. This qualitative research uses Friedrich Schleimacher's hermeneutic method (1764-1834). This study finds that in the construction of Fazlur Rahman's thought, God is One and the First. God is not a dimension, but He is the creator of the dimensions. The existence of God can be found with Himself because He is the evidence for all things. For this reason, everything created by God has a (teleological) purpose, namely as proof of His functional existence. God is transcendent and immanent. Transcendent God implies that God is completely different from all His material creatures. At the same time, the immanent God is "along" with His creation. God has a direct relationship with his creation, it does not mean that God is in everything that exists in nature, even though His presence is all-encompassing.
\end{abstract} Keywords: Fazlur Rahman; The Being of God; Transcendent; Immanent; Hermeneutic.

\begin{abstract}
Abstrak
Artikel ini menganalisis tentang kontruksi pemikiran Fąlur Rahman tentang Tuban. Penelitian ini adalah penelitian kualitatif dengan menggunakan metode hermeneutika Friedrich Schleimacher (17641834). Studi ini menemukan bahwa dalam kontruksi pemikiran Fąlur Rabman Tuban adalah Esa dan Yang Pertama. Tuban bukanlah dimensi, tapi Ia pencipta dimensi-dimensi yang wujud. Wujud Tuban dapat ditemukan dengan diri-Nya sendiri, karena diri-Nya merupakan bukti bagi segala sesuatu. Untuk itu, dalam pemikiran Fazlur Rabman segala yang diciptakan Tuban mempunyai tujuan (teleologis) yaitu sebagai bukti wujud-Nya yang bersifat fungsional. Kemudian, bagi Fazlur Rabman Tuban bersifat transenden dan imanen. Transenden Tuban mengandung makna babwa Tuban sama sekali berbeda dengan segala makhluk-Nya yang bersifat materi. Sedang imanen Tuhan adalah "bersama-sama" dengan ciptaan-Nya. Tuban mempunyai bubungan langsung dengan ciptaannya, bukan berarti Tuhan ada di dalam setiap sesuatu yang ada di alam, sungguhpun kehadiran-Nya serba meliputi.
\end{abstract}

Kata Kunci: Fąlur Rabman; Wujud Tuhan; Transenden; Imanen; Hermeneutika. 


\section{INTRODUCTION}

Divine philosophy is the highest principle in philosophy because it is metaphysical ${ }^{1}$, both as a world view and a way of life $^{2}$. It is said to be metaphysical (literally means something behind nature or what exists before nature $)^{3}$, because the philosophy of divinity is relevant to the study of God, which is abstract and cannot be proven empirically. Because God is abstract, then $\mathrm{He}$ is not limited by space and time. For that, God does not need space and time in His existence; something that is abstract or immaterial does not need and is not limited by space and time. Strictly speaking, divine philosophy deals with immovable and separate substances from matter, as opposed to physics or natural philosophy which deals with moving and material substances ${ }^{4}$.

Although belief in God is emotional by nature, it is very important to be supported by rational arguments. For this reason, in Islamic philosophy, the philosophy of divinity becomes the main and main study, because it becomes the basis for the development of philosophy, both as a material object and a formal object (point of view). Islamic philosophers believe that God must exist (wajib al-wujud). God is Perfect and immaterial. In explaining the existence of God, the object of the form used by Islamic philosophers is philosophical arguments (deep), and the truth can be accepted by human reason (logical-rationalist). The use of philosophicallogical-rationalist arguments about God strengthens belief in Him.

1 Martijn Buijs, "Theology, Ontotheology, and Eschatology in Schelling's Late Thought," The Journal of Speculative Philosophy 30, no. 3 (2016): 373, https://doi.org/10.5325/jspecphil.30.3.0373.

2 Alia Al-Saji and Brian Schroeder, "Introduction," The Journal of Speculative Philosophy 30, no. 3 (January 2016): 235-41, https://doi.org/10.5325/jspecphil.30.3.0235.

3 Charles Genequand, "Metaphysics," in History of Islamic Philosophy, ed. Seyyed Hossein Nasr and Oliver Leaman (London: Routledge, 1996), 1381, https://doi.org/10.4324/9781003070733. Philosophy.

4 Genequand, "Metaphysics," in History of Islamic
In Islamic philosophy, philosophers have formulated God with various concepts. Its purpose is to explain the oneness of God in a logical-philosophical way. For this reason, the concept of God is related to the formulation of the oneness of God (tawhid). In Islam, this term relates to monotheism (oneness of God/monotheism), which is the main teaching in Islam $^{5}$. Tawhid is the acknowledgment of universal truth that expresses the actual state of everything because everything is under the Oneness of God'. In Islam, the concept of monotheism is based on the shahada formula "la ila ha illa Allab" (there is no god but Allah). This formula shows the belief that God is One (Sunday). The word "One" is interpreted as "single," "only" or "unique," because he is not counted, there are no two or three, nor is there any peer. Thus, monotheism is a theoretical description and working mechanism to unite God $^{8}$.

In the Islamic philosophy, Muslim philosophers are very intense in studying God, thus causing debate among them in formulating and formulating it. Al-Kindi, Ibn Sina, Suhrawardi al-Maqtul and Muhammad Iqbal and Fazlur Rahman, were among the Muslim philosophers who studied divinity with various thought concepts. The goal of Muslim philosophers in formulating the concept of divinity is to unite God in all his monotheisms.

As a modern Islamic philosopher, one of the criticisms of Fazlur Rahman for modernity is that many modern humans do not believe in the existence of God, the Creator of the Universe.

${ }^{5}$ Mulyadhi Kartanegara, Lentera Kehidupan: Panduan Memahami Tuhan, Alam Dan Manusia (Bandung: Mizan Pustaka, 2016), 15

${ }^{6}$ William C. Chittick, Science of the Cosmos, Science of the Soul: The Pertinence of Islamic Cosmology in the Modern World (Oxford: Oneworld Publication, 2007), 111.

${ }^{7}$ Kartanegara, Lentera Kebidupan: Panduan Memahami Tuhan, Alam Dan Manusia.

${ }^{8}$ Hasan Hanafi, Dari Akidah Ke Revolusi, ed. Dkk terj. Asep Usman Ismail (Jakarta: Paramadina, 2003), 9. 
Although belief (faith) in the existence of God is emotional, a believer still needs rational arguments for the existence of God to strengthen his faith. Secular modern humans often question and doubt the existence of God, because for him everything is always measured by the five senses, so that everything that is not empirical or "tangible" is considered non-existent".

Interestingly, Fazlur Rahman as an Islamic philosopher and a modernist shows a new reading of what monotheism in the face of modernity looks like-so that Fazlur Rahman's monotheistic thinking can be used as a "metaphysical/theological basis" in today's modern life. In a sense, Fazlur Rahman's divine thought can be a solution to the spiritual dryness felt by modern society, or at least as a reference for thinking about how to view God or build monotheism in today's life.

Based on the description above, how is the construction of Fazlur Rahman's thought as a contemporary South Asian Islamic philosopher in viewing God. How Fazlur Rahman constructs the conception of God and his existence, and whether God is immanent or transcendent or has both elements. So, in this study, we will focus on examining how the construction of Fazlur Rahman's thoughts about God is.

This type of research is qualitative and has a library research pattern. This study examines the thoughts of a character (philosopher) in his work. The existing data is then classified based on primary and secondary data. Primary data are textual data originating from books written by Fazlur Rahman that are relevant to his philosophical thoughts about God, nature, and humans, namely; Prophecy in Islam: Philosopy and Ortodox, The Philosophy of Mulla Shadra, Mayor Themes of The Qur'an, Islam, and Islam and Modernity: Transformation of an Intellectual Tradition.

${ }^{9}$ Kartanegara, Lentera Kebidupan: Panduan Memahami Tuhan, Alam Dan Manusia.
Meanwhile, secondary data consists of works or research from other people that explain Islamic philosophy and Fazlur Rahman's thoughts, such as John L. Esposito (ed.,), The Oxford Ensiklopedia of The Modern Islamic World, Earle H. Waugh and Frederick M. Denny (ed.,), The Shaping of an American Islamic Discourse: A Momorial to Fazlur Rabman, Sayyed Hossein Nars and Oliver Leaman (ed.,), History of Islmic Philosophy, and Mulyadi Kartanegara, Nalar Religius: Memahami Hakikat Tuban, Alam dan Manusia,

Existing data were collected through the author's library to be used as material in understanding and describing Fazlur Rahman's philosophical thoughts related to divinity, philosophy of the universe and human philosophy. All data is library data because this research is library research. The data collected is then organized based on the research framework, such as the separation of primary and secondary data to facilitate the implementation of research.

The methodology used in this study is a philosophical (Islamic) research methodology. In building Fazlur Rahman's philosophy, the researcher uses the "Metaphysical Trilogy" theory formulated by Mulyadi Kartanegara in his book Nalar Religius: Memahami Hakikat Tuban, Alam dan Manusia, which is about the philosophy of God, nature and humans. The three material objects of this ontology, explained Mulyadi, can be used as a reference in knowing and understanding the world view and philosophy of life (weltanschaunng) of a philosopher. Fazlur Rahman in his various works, namely Prophecy in Islam: Philosophy and Orthodoxy, The Philosophy of Mulla Shadra, Mayor Themes of The Qur'an, Islam and Modernity: Transformation of an Intellectual Tradition.

Even though Fazlur Rahman in his work does not include the word "philosophy" or "falsafah" literally as the title of his book, some of his works that the researcher has examined contain logical, critical and philosophical concepts and arguments. So the researcher will make a 
composition of Fazlur Rahman's philosophical thoughts from his various works integrally and comprehensively, so that it can be used as a word view and weltanchoung in understanding his philosophical concepts and thoughts.

Because the material object is a character (philosopher) who has died, it is assisted by a historical approach. It is done so that it can be seen integrally the historical continuity of the development of Fazlur Rahman's philosophical thought and the thinkers who influenced it. In addition, this research also uses a sociological approach, namely in exploring the socio-cultural intellectual context faced by Fazlur Rahman.

In analyzing the data, the researcher used the hermeneutic method. Hermeneutics is an interpretive method that aims to understand texts, especially biblical texts, starting from their characteristics, both objective (the grammatical meaning of words and their historical variations), and subjective (the intended intent of the author $)^{10}$. The hermeneutic method is used to interpret Fazlur Rahman's philosophical thoughts. This method can investigate the origin of the situation that gave birth to a character's thoughts or ideas and explore that a character in acting or thinking is influenced by encouragement from himself and encouragement from outside ${ }^{11}$.

In this study, the researcher used the hermeneutic method Friedrich Schleimacher (d.1834). According to Schleimacher that in order to master the alienation of a text and understand it well, we must try to understand the author, we need to get out of the era in which we live now, reconstruct the author's era, and re-present the state in which the author was when he wrote the text (his work). We must identify with the original reader to whom the text is concerned and thus become contemporaries with him in identifying

10 Donny Gahral Adian, Pilar-Pilar Filsafat Kontemporer (Yogyakarta: Jalasutra, 2002), 130.

11 Taufik Abdullah and M. Rusli, Metodologi Penelitian Agama: Sebuah Pengantar, ed. Taufik Abdullah (Yogyakarta: Tiarawacana, 1989), 73. with the author. We have to imagine the author's thoughts, feelings, and intentions. We seem to have to move into the inner life of the author ${ }^{12}$.

\section{LITERATURE STUDIES}

This research focuses on the theme of God in the construction of Fazlur Rahman's philosophy. So far, the researcher's review of studies and discussions about Fazlur Rahman's thoughts have been carried out by many previous writers and researchers. From several research results and writings related to Fazlur Rahman, no one has studied Rahman's philosophical thoughts, which are the same as the subject matter, the theory used and the approach in this research.

Research in the field of law, which has been carried out, includes research on Taufik Adnan Amal's thesis entitled "Islam dan Tantangan Modernitas: Studi atas Pemikiran Hukum Fålur Rabman". Taufik only expressed Fazlur Rahman's important ideas about Islamic law. The method used in this research is descriptive and analytical. At the descriptive level, Taufik presents Fazlur Rahman's legal thoughts by himself, while at the analytical level, he analyzes the context of Fazlur Rahman's legal thoughts with the modern world ${ }^{13}$.

Likewise, the research of Ghufran A. Mas'adi, Pemikiran Fąlur Rahman tentang Metodologi Pembaruan Hukum Islam which offers a methodology of Islamic law reform. This process shows the continuity of a continuous process of classical thought ${ }^{14}$. Both Taufik and Mas'adi studies deserve appreciation because they have made serious efforts to explain the renewal of Fazlur Rahman's legal thought.

12 Muhammad Akram, "Beyond Dichotomies: The Import of Gadamer's Hermeneutics for the Debate of Relationship between Theology and Religious Studies," Islamic Studies 52 (June 2013): 137-53.

13 Taufik Adnan Amal, Islam Dan Tantangan Modernitas (Bandung: Mizan, 1990), 43.

14 Ghufron A. Mas`adi, Pemikiran Fazlur Rabman

Tentang Metodologi Pembaruan Hukum Islam (Jakarta: RajaGrafindo Persada, 1997), 9. 
In the field of politics, M. Hasbi Amiruddin researched "Konsep Negara Islam menurut Fazlur Rabman." In this research, Hasbi positioned the intellectual figure of Fazlur Rahman as a politician based on his experience as Director of the Islamic Research Institute and Advisory on Islamic Ideology, Pakistan, during the government of the President of Pakistan, Ayub Khan. In this study, Hasbi examines Fazlur Rahman's ideas and movements in the context of building a more substantive Islamic state; what is required by Islam from a country that is following Islamic teachings as stated by the Qur'an and Sunnah. As for data processing, he uses the analytical-critical method. Thus, this research does not trace the slightest study of Fazlur Rahman's philosophical thought that the researcher will do.

While in the field of Islamic theology, such as research conducted by Abd A'la, in his dissertation at IAIN Syarif Hidayatullah, he wrote "Pandangan Teologi Fazlur Rabman (Studi Analisis Pembaruan Teologi Neo-Modernisme)". In this research, A'la sees Fazlur Rahman's position as a neo-modernist Islamic theologian who reforms in the study and discussion of Islamic theology in the modern era with a hermeneutical and comparative approach. The main themes of the study of Fazlur Rahman's theological views are the problem of the oneness of God, God's deeds, revelation and prophethood, human knowledge and actions, the universe, demons and the principle of evil, and eschatology. Based on the subject of his discussion, A'la concluded that one of the characteristics of Fazlur Rahman's theological thinking is in his efforts to link theology, ethics and figh in a harmonious pattern of interdependence relationships ${ }^{15}$.

Somewhat in line with Abd A'la, Ahad M. Ahmed in his thesis at the International Islamic University, Islamabad, Pakistan researching "The

15 Abd A'la, "Pandangan Teologi Fazlur Rahman: Studi Analisis Pembaruan Teologi Neo-Modernisme" (IAIN Syarif Hidayatullah, 1999), 12.
Theological Thought of Fazlur Rabman: A Modern Mutakallim". Sunday's research seems very simple because it is descriptive and universal. He discussed Fazlur Rahman's thought with two main themes, namely 1) God; the function of nature on the concept of divinity, the urgency of God's existence, God's relationship with nature and humans, pragmatic and moral arguments against belief in God, human knowledge, the concept of faith, human actions; and prophetic concepts. 2) Miracles, moral elan in the Qur'an, the Prophet's intellect, and the nature of the Prophet ${ }^{16}$.

The research that has been done in the field of Islamic philosophy is Fatimah Husein's research, thesis at McGill University Canada, with the title "Fazlur Rabman's Islamic Philosopby". Fatimah's research is very urgent to be appointed. Because he tries to trace Fazlur Rahman's philosophical thoughts, especially about his role in interpreting the messages of the Qur'an for the needs of the contemporary world ${ }^{17}$. For this reason, the discussion cannot be separated from Fazlur Rahman's thoughts about God, humans, the universe and eschatology; which is also discussed in this dissertation. However, Fatimah put this discussion on one of her sub-discussions, namely chapter $3, b^{18}$ with a general explanation, less in-depth and only specifically referring to one of Fazlur Rahman's works, namely Major Themes of the Qur'an. It is of course different from the dissertation research that the researcher is doing. The problem is to state the problem of God, nature, and humans as the main and main object of study in an integral, radical and comprehensive manner which is not devoted to the book Major Themes of the Qur'an, but is also combined with

16 Ahad M. Ahmad, "The Theological Thought of Fazlur Rahman: A Modern Mutakallim" (Univercity Islamabad, n.d.), 1.

17 Fatimah Husein, Fazlur Rahman's Islamic Philosophy, Thesis Mas (Montreal: McGill University, 1997), 32-33.

${ }^{18}$ Husein, Fąlur Rabman's Islamic Philosophy. 
Fazlur Rahman's other relevant works are Prophey in Islam: Philosophy and Orthodoxy, and The Philosophy of Mulla Sadra.

Likewise, the research conducted by Hamdan Akramullah with the title "Aspek-aspek Neo-modernisme Faqlur Rabman dan Kontribusinya bagi Epistimologi Islam ${ }^{19}$, thesis (unpublished). Hamdan positioned Fazlur Rahman as a neo-modernist figure in the study of Islamic epistemology with various aspects. Thus, Hamdan's research has a correlation with the research that the researcher will do, which is both in the Islamic philosophy family. However, Hamdan did not "glitch" research on Fazlur Rahman's philosophical thoughts about God, nature, and humans in his subject matter.

Earle H. Waugh and Frederick M. Denry, two North American intellectuals, wrote "The Shapping of an American Islamic Discourse; A Memorial to Fazlur Rabman". This book was written as a reflection of Fazlur Rahman's contribution to the development of Islam in North America and the role of American Muslims on the international Islamic stage.

The writings that are still "preliminary studies" in the form of articles about Fazlur Rahman are the writings of Syafi'i Ma'arif ${ }^{20}$, Dawam Raharjo $^{21}$, and Nurcholish Madjid ${ }^{22}$. They generally express some information and appreciation about the personality and life of Fazlur Rahman and the main points of his religious thoughts. In these writings, it seems that

19 Hamdan Akramullah, “Aspek-Aspek NeoModernisme Fazlur Rahman Dan Kontribusinya Bagi Epistimologi Islam" (Universitas Gadjah mada, 2002), 2.

20 Ahmad Syafi'i Ma'arif, "Noe-Modernisme Dan Islam Di Indonesia: Mempertimbangkan Pemikiran Fazlur Rahman," in Peta Bumi Intelektual Islam Indonesia, ed. Ahmad Syafi'i Ma'arif (Bandung: Mizan, 1994), 135.

21 Dawam Raharjo, Islam Dan Masyarakat: Pandangan Fazlur Rabman," Dalam Intelektual Intelegensia Dan Perilaku Politik Bangsa, Dawam Raha (Bandung: Mizan, 1993), 272.

22 Nurcholish Madjid, "Fazlur Rahman Dan Rekonstruksi Al-Qur'an, Dalam Islamika," Islamika, no. 2 (1993): 23-28. they want to awaken and develop the intellectual figure of Fazlur Rahman with various sparks of his thoughts in various aspects. However, this study does not present the figure of Fazlur Rahman as an Islamic philosopher in the modern era and about his philosophical thoughts.

From some of the research results conducted by the researchers above, explicitly, they have never formulated Fazlur Rahman's philosophical thoughts, which are the same as this research. Likewise, from the point of view of the theory used and its analysis, as a parameter to see the perspective of Fazlur Rahman's philosophical thought within the framework of modern Islamic philosophy, it is completely different from the theory and analysis of the research that the researcher did.

\section{THE CONCEPT OF GOD}

According to Fazlur Rahman, the Qur'an conveys the idea of one God to humans ${ }^{23}$. God is not a dimension. In contrast, the dimensions that exist were created by God. God gives meaning and life to everything. God is infinite (finite), while other than Him is finite. Because apart from him being limited, he is God's creation. Therefore, it is very logical that only one (one) God is also the First ${ }^{24}$. God is not a dimension. In contrast, the dimensions that exist were created by God. God gives meaning and life to everything. God is infinite (finite), while other than Him is finite. Because apart from him being limited, he is God's creation. Therefore, it is very logical that only one (one) God is also the First. For this reason, in explaining the oneness of God, it must be based on a logical thinking framework. In terms of religion God cannot personify Himself in many forms. If this happens, then God will automatically be lowered to a human level. To

23 Fazlur Rahman, Islam and Modernity: Transformation of an Intellectual Tradition (Chicago: The University of Chicago Press, 1982), 4.

24 Fazlur Rahman, Major Themes of the Qur'an (Chicago: University of Chicago Press, 1989), 4. 
maintain the holiness and unity of God, God must be purely spiritual and cannot be identified with His creation $^{25}$. Thus, philosophicallymathematically, the oneness of God means describing everything other than God as being plural or plural and limited.

The above indicates that God cannot be compared with everything He created: God created everything in pairs to distinguish His own oneness from the plurality of His creatures. Creation is impossible without duality, like heaven and earth, man and woman, day and night, sun and moon, land and sea, winter and summer, light and darkness, faith and disbelief, happiness and misery, sweet and bitter ${ }^{26}$.

Fazlur Rahman's divine philosophy was born from the concept of modern human divine thought which departed from the polytheism of ignorant Arabs who believed in and asked for help from many gods other than Allah $^{27}$, as revealed by Allah in the Qur'an;

"O you who believe, take out some of the wealth We have given you before the day (of Judgment) comes, when there is no more bargaining, friendship, and help. Indeed, it is the disbelievers who are the wrongdoers. Allah is God, there is no god but $\mathrm{He}$ who lives, does not sleep and does not sleep. He is the owner of all that is in the heavens and the earth. Who can help except with His permission? He knows everything in front of them and behind them, while they do not know what He has permitted. His dominion covers the heavens and the earth which $\mathrm{He}$ cares for effortlessly. He is the Greatest and Most Great." (Qs. Al-Baqarah/2: 254-255).

In Fazlur Rahman's hermeneutic understanding, the two texts of the Qur'anic

${ }_{25}$ Tan Malaka, Madilog: Materialisme, Dialektika, Dan Logika (Jakarta: Pusat Indikator, 1999), 387.

${ }^{26}$ Sachiko Murata, The Tao of Islam: Kitab Rujukan Tentang Relasi Gender Dalam Kosmologi Dan Teologi Islam (Bandung: Mizan, 1998), 165.

27 Fazlur Rahman, The Philosophy of Mulla Sadra (New York: State University of New York Press Albany, 1975), 267. verses above, in addition to explaining God as Almighty God, also express His infinite love (taubid rububiyab). God's power and love for the creatures He created is to strengthen belief and faith in His oneness. Thus, the creation of nature and humans, on the one hand, and nature for humans, on the other, is a sign of evidence of Allah's mercy. Therefore, His power, creation and love are identical and equally broad, because they both explain the oneness of God as the almighty and all-loving to all His creations, especially humans; "He has clothed himself with mercy" (Surah al-An'am [6]: 12) and "My mercy is for everything" (Surah al-A'raf [7]: 156).

The accumulation-synthesis of Fazlur Rahman's divine philosophy was born as a response to the statement of modern Western thinkers who think that God in Islam is an unloving God, far from humans, unpredictable, despotic, authoritarian, misleading some people and giving some guidance to some people, and make a decision for some people to heaven and some people to hell. Western thought is in line with the framework of science and philosophy that developed in the modern West. Since the beginning of modern times, science in the West has been separated from philosophy. Philosophy is no longer synonymous with science or no longer includes science. The area of scientific study is what exists, as far as the human senses can perceive, without or through the intermediaries of advanced technology created by humans. The study area of science is the empirical world, the physical world, or the material world. What cannot be grasped by the five senses, even though it is believed to exist by many humans, such as God is not included in the study of science $^{28}$.

28 Ahmad Tafsir, Filsafat Umum: Akal Dan Hati Sejak. Thales Sampai Capra (Bandung: PT Remaja Rosdakarya, 2000), 126. 


\section{EXISTENCE OF GOD}

The construction of Fazlur Rahman's philosophical thoughts about the existence of God was built based on criticism of several understandings that developed in modern times ${ }^{29}$, namely; first, the understanding of the Sufism (such as Jalaluddin Rumi), who believe that Allah created the universe as a game, such as a hadith saying "I am a hidden wealth, but I am found. That is why I created." This expression indicates that the nature created by God is a game to be used as a means to find Him. Second, the notion of atheism (as initiated by Karl Marx) which does not believe in the existence of God. Third, materialistic naturalism (as initiated by Sigmund Freud) which considers nature and everything in it to exist as material and has no cause ${ }^{30}$. Fourth, modern science (such as the opinion of PierreSimon de Laplace) which believes in the cyclical motion of the universe which has no purpose of creation. For this reason, Fazlur Rahman emphasized, if the universe is a game, then the explanation of the Qur'an about guidance, error and God's judgment has no meaning and is only an illusion ${ }^{31}$

Based on the criticism above, Fazlur Rahman formulated a synthesis that God as creator, sustainer, guide and regulator is a manifestation of His grace to explain His existence in creating the universe and humans. Fazlur Rahman emphasized that the Qur'an does not explain "proving" the existence of God, but "shows" a way to know God through the universe. If the universe evolves not according to its rules, this shows the nature of its dependence on God to regulate it. Alternatively, vice versa, if the universe evolves according to its rules, of course it does not depend on others (God). However, the universe cannot explain its origin. For that, the universe definitely needs a creator,

\footnotetext{
${ }^{29}$ Rahman, Major Themes of the Qur'an.

${ }^{30}$ Rahman, The Philosophy of Mulla Sadra.

${ }^{31}$ Rahman, Major Themes of the Qur'an.
}

namely God, so that the universe evolves according to its rules ${ }^{32}$

Fazlur Rahman explained that the comprehensive order of nature did not happen by chance, but had a purpose. Orders that occur by chance are not cohesive, irrational and have no fundamental purpose. By combining the thoughts of Aristotle, Neoplatonic and Ibn Sina, Fazlur Rahman reveals that God is the efficient cause (al'illab al-fa'iliyab) and the final cause of the universe. As an efficient cause, God is the First Mover and created the universe or the first Creator of matter in motion. Meanwhile, as the final cause, the aim and purpose of the natural movement is to show the existence of God, as the final mover. For this reason, belief in God will be stronger if it is supported by empirical arguments that show the existence of $\mathrm{God}^{33}$, as the controller of the universe according to His intended purpose. With this empirical evidence, the belief in the existence of God, apart from being the creator, is also the regulator of nature, can be understood logically and philosophically.

In the author's analysis, the accumulation of the synthesis of Fazlur Rahman's philosophy about the existence of God is influenced by alKindi's philosophy of divinity, who also put forward the argument of natural order to find the existence of God. This orderly and tidy nature, stated al-Kindi, cannot be ordered and controlled without someone who regulates and controls it. Because nature is limited, the regulator and controller of nature is certainly something outside of nature and is not the same as a finite nature. That substance cannot be seen with the human eye empirically, but can be known by looking at the signs found in nature, that substance is called Allah. Al-Kindi's thought adopted by Fazlur Rahman is that the occurrence of diversity and uniformity in nature is not by chance, but that someone must have designed it. It is impossible

\footnotetext{
32 Rahman.

33 Rahman.
} 
for the designer to design because nature is material, changing and will end or be limited. Whereas something that ends, cannot happen by itself. Instead, the cause must be outside nature, namely the One who is the Greatest, Most Noble and first in his form from nature, which is called Allah SWT ${ }^{34}$.

Fazlur Rahman's argument above can be understood that he explains the form of God based on observations of phenomena that occur in nature. He used the mortal and changing nature as a reference to understand and think about the existence of God. Thus, through the form of nature, the form of God as the creator of nature can be known and thought of by humans. In another sense, God is the Creator of nature, and from God's creation this can be known and used as an argument to prove the existence of God.

The argument for the existence of God as the preserver of nature formulated by Fazlur Rahman seems to agree with the argument put forward by Ibn Rushd. According to Ibn Rushd, God's providence (inayah al-Ilabiyab) to the universe is very compatible with human life. This conformity is unlikely to have happened by chance, but it shows the existence of a very wise creator. All events in nature are very compatible with human nature, such as day, night, sun, moon, plants, animals and human limbs. All of that is impossible to maintain and maintain without a wise caretaker. The custodian is Allah SWT, according to the confirmation of the verses of the Qur'an Surah al-Naba': 6-7. "Have We not made the earth as a stretch and the mountains as pegs."

For humans to contemplate God means that he can understand His form. With a deep understanding, the existence of God is no longer believed by humans as something "irrational" and "unreasonable", but turned into the "supreme truth". To achieve the Supreme Truth, humans must "listen" to the calls of the Qur'an to humans to use their heart/mind and hear about the

\footnotetext{
${ }^{34}$ Rahman.
}

existence of God. Therefore, to make people believe in God, what is needed is "theological" arguments and "theological-philosophical" about God's commands that are relevant to moral obligations or prohibitions, because the principle of teaching is based on commands or prohibitions from $\operatorname{Lord}^{35}$. To that end, Fazlur Rahman formulated principles that remind humans of the existence of God, namely: first, that everything other than God, including the entire universe (which has "metaphysical" and "moral" aspects), depends on Him. Second, the Greatest and Wise, in essence, a Most Gracious God. Third, these aspects require the relationship between God and humans, as a consequence of which is the relationship between human beings. This relationship requires rules for humans as individuals and their existence as social beings ${ }^{36}$.

\section{TRANSCENDENCE (TANZIH) AND GOD'S IMMANENCE (TASYBIH)}

There are differences and theoretical debates between philosophers (peripatetics) and Sufis about the concept of immanence and transcendence of God, where Islamic philosophers emphasize the transcendence of God and Sufis are more intense with the immanence of God, so Fazlur Rahman constructs a synthesis in the form of reconciling the accumulated thoughts of philosophers and Sufis. This reconciliation of Fazlur Rahman's accumulation is reflected in the concept that God is both transcendent and immanent. Transcendent God implies that God is entirely different from all His material creatures ${ }^{37}$. Fazlur Rahman revealed, God is transcendent with His infinity. Thus, the transcendence of God is reflected like God, who

35 C. Stephen Evans, "God's Command. By John E. Hare.," The Journal of Theological Studies, October 2016, flw158, https://doi.org/10.1093/jts/flw158.

${ }^{36}$ Rahman, Major Themes of the Qur'an.

37 Murata, The Tao of Islam: Kitab Rujukan Tentang Relasi Gender Dalam Kosmologi Dan Teologi Islam. 
is perfect and is not limited by space and time ${ }^{38}$. God, beyond human beings, even beyond the universe, "It is Allah Who created the heavens and the earth in six days, then $\mathrm{He}$ ascended to His Throne; there is no guardian or helper for you but Him. Don't you remember it? He governs all affairs in the heavens and the earth" (Surah alSajadah [32]: 4-5).

Even though God's transcendence includes all of His creation, it does not mean that His transcendence is one-sided. God's transcendence emphasized Fazlur Rahman, "together" with His creation (immanent) ${ }^{39}$, "We are closer to man than the veins in his neck" (Surat Qaf [50]: 16). For that, if a human being goes astray, with all his heart regrets his actions and asks forgiveness from $\mathrm{Him}$, then $\mathrm{He}$ immediately returns to him because $\mathrm{He}$ is Most Gracious, Most Merciful and the light that illuminates so that all things find life. The purpose of the Qur'an to confirm the transcendence and immanence of God is to show the implications when humans identify all that is finite (the universe and humans) with the Infinite One. In other words, humans will not be able to place other gods between Him and His creation, because $\mathrm{He}$ has a direct relationship with His creation. Therefore, even though God is not part of nature, it does not mean that God is in everything that exists in nature, even though His presence is all-encompassing. God is real. Rational and cultural approaches and thoughts cannot narrow him down ${ }^{40}$.

Even though Fazlur Rahman admits the immanent aspect of God, he criticizes the concept of pantheism formulated by orthodox Sufis. According to pantheism, the whole universe (cosmos) is God, and God is the whole universe. Things that can be perceived with the five senses are part of God. Humans, animals, plants, and

\footnotetext{
${ }^{38}$ Rahman, Major Themes of the Qur'an.

39 Rahman.

${ }^{40}$ Rahman.
}

inanimate objects are part of God. God is very close to nature. Because the whole cosmos is one, there is only one God; only God has appearances or ways of being in nature. God, besides One, is also omnipotent and unchanging. The sensory realm is an illusion or fantasy because it is always changing. There is only one true being, namely God $^{41}$.

In Fazlur Rahman's analysis, pantheism is an assimilation of the concept of determinism of the orthodox Sunni theologians with the concept of wabdat al-wujud in Sufism. The mystical privilege of the Sufi should not be contradicted by the teachings of the orthodox Sunni theologians. Because the relationship between a holy person (who has mystical privileges) and God there is a spiritual bond ${ }^{42}$. According to Fazlur Rahman, this doctrine destroys monotheism from an ethical point of view because it negates the difference between good and evil. That is, this doctrine changed from Sufism to a theological statement; that "all actions are created by God", to the view that "all actions are works of God", to the theological doctrine "nothing exists but God". ${ }^{43}$ Theologically this thinking leads to the bad deeds are the actions of God. Strictly speaking, that God does and is related to evil. It has implications for immanence moral/ethical values that cannot be relied on God.

In addition to criticizing the concept of pantheism, Fazlur Rahman also criticized the extreme zubud life carried out by Sufis in getting closer to God. In his critique of extreme zubud, Fazlur Rahman argues that the practice of zubud carries out extreme reactions (rejects) to worldly life because there is no integrality between worldly life and the hereafter. According to him, this kind

41 Amsal Bakhtiar, Filsafat Agama 1 (Ciputat: Logos Wacana Ilmu, 1997), 93-94.

42 Rynold A. Nicholson, Gagasan Personalitas Dalam Sufisme Terj. A. Shihabulmillah (Yogyakarta: Pustaka Sufi, 2002), 41.

${ }^{43}$ Fazlur Rahman, Islam (Chicago: The University of Chicago Press, 1979). 
of zubud contradicts the Qur'an and the Sunnah of the Prophet. Whereas the Qur'an and the Sunnah of the Prophet call upon Muslims to sacrifice pleasure, if necessary, possessions "in the way of Allah" or for the common good, i.e. a moral social order. However, zubud who rejects the world's life calls for not having anything in the world, so that he cannot sacrifice or use something that he does not have as a form of imitating God's immanence in humans. It is contrary to the moral ideals put forward by the Qur'an and the sunnah of the prophet. This genealogy of extreme zuhud, said Fazlur Rahman, dates back to the collapse of leadership and political authority after 'Ali ibn Abu Talib, at the time of the upheaval between the Umayyad, Khawarij, Shi'a and supporters of 'Abdullah ibn al-Zubair who filed the following demands. conflicting demands among Muslims ${ }^{44}$.

God's transcendent nature can be seen through the existential essence of His creation. Where religious symbols become a means of establishing a relationship between God and nature, and between God and humans. God who is immaterial, in His transcendence, can give light in the reality of nature and human reality. Meanwhile, the essence of God's immanent existence is understood at the level of natural reality and human reality given by God with spiritual and intellectual elements. Through the spiritual and intellectual elements of natural reality and human reality, the immanence of God is realized, both essentially and existentially. So that the transcendence and immanence of God always exist in the reality of human life in nature ${ }^{45}$.

From the construction of Fazlur Rahman's synthesis above, it can be concluded

44 Fazlur Rahman, Islamic Methodology in History (Central Institute of Islamic Research, 1965), 166.

45 Nikolaos Loudovikos, "Being and Essence Revisited: Reciprocal Logoi and Energies in Maximus the Confessor and Thomas Aquinas, and the Genesis of the Self-Referring Subject," Revista Portuguesa de Filosofia 72, no. 1 (January 2016): 117-46, http://www.jstor.org/stable/43816277. that Allah as the Creator and Sustainer of nature is transcendent. God's transcendence encompasses everything in the heavens and on earth. God's transcendence is described in His oneness and power over nature and human beings ${ }^{46}$. The concept of God as transcendent explains the absolute nature of God which material symbols cannot express because it is to maintain the holiness of God from all material things ${ }^{47}$. Even though God is transcendent, $\mathrm{He}$ is different from nature and humans, as His creatures. Meanwhile, immanent God means that God is very close to nature, especially humans. By placing the Qur'an at the center of his exposition of thoughts ${ }^{48}$, Fazlur Rahman said that God's immanence is not only near, but "closer than human veins". The closeness between God and humans remains at the spiritual (spiritual) and not material (physical) level. Because as a follower of rationalism, Fazlur Rahman rejects the immanence of God which is believed by orthodox theologians who take refuge in the power and will of $\mathrm{God}^{49}$.

The immanence of God, further stated by Fazlur Rahman, exists "with" everything; $\mathrm{He}$ is the cause of the integrity of everything. Since everything is related to God, everything is through and about others, related to God. So, God is the meaning of reality, which is a meaning

46 Claudia Welz, "Difficulties in Defining the Concept of God: Kierkegaard in Dialogue with Levinas, Buber, and Rosenzweig," International Journal for Philosophy of Religion 80, no. 1 (August 2016): 61-83, https://doi.org/10.1007/s11153-015-9544-z.

${ }^{47}$ Aydogan Kars, "Two Modes of Unsaying in the Early Thirteenth Century Islamic Lands: Theorizing Apophasis through Maimonides and Ibn 'Arabī," International Journal for Philosophy of Religion 74, no. 3 (December 2013): 261-78, https://doi.org/10.1007/s11153-012-9381-2.

48 Katajun Amirpur, "New Islamic Thinking in Islam: The Jihad for Democracy," Review of Middle East Studies 51, no. 1 (February 8, 2017): 77-147, https://doi.org/10.1017/rms.2017.1.

49 Ramona Hosu, "God's Word Among Hermeneutics, Exegesis and Homiletics," Journal for the Study of Religions and Ideologies 16, no. 48 (January 2017): 141-46. 
that is manifested, explained and conveyed by nature and humans. Therefore, everything that exists in the universe is a "sign" of God's existence because God is not a part of the universe's parts. God is not an existence among other existences ${ }^{50}$. Thus, God's transcendence and immanence for Fazlur Rahman serves to describe God's existence as a whole.

\section{CONCLUSION}

Based on the discussion above, it can be concluded that Fazlur Rahman's divine philosophy states that God is One and the First. God is not a dimension, but $\mathrm{He}$ is the creator of the dimensions. God gives meaning and life to every being. God is unlimited, while other than Him is finite. God is not part of nature. God's power is manifest in His loving creativity. Thus, the form of God can be found with Himself because $\mathrm{He}$ is the evidence for all things.

For this reason, everything created by God has a (teleological) purpose, namely as evidence of His functional form. God is transcendent and immanent. Transcendent God implies that God is completely different from all His material creatures. God is transcendent with His infinity. God's transcendence is reflected like God who is perfect and is not limited by space and time. At the same time, the immanent God is "together" with His creation. God has a direct relationship with His creation, it does not mean that God is in everything that exists in nature, even though His presence is all-encompassing.

\section{REFERENCES}

A'la, Abd. "Pandangan Teologi Fazlur Rahman: Studi Analisis Pembaruan Teologi NeoModernisme." IAIN Syarif Hidayatullah, 1999.

Abdullah, Taufik, and M. Rusli. Metodologi Penelitian Agama: Sebuah Pengantar. Edited by

\footnotetext{
${ }^{50}$ Rahman, Major Themes of the Qur'an.
}

Taufik Abdullah. Yogyakarta: Tiarawacana, 1989.

Adian, Donny Gahral. Pilar-Pilar Filsafat Kontemporer. Yogyakarta: Jalasutra, 2002.

Ahmad, Ahad M. "The Theological Thought of Fazlur Rahman: A Modern Mutakallim." Univercity Islamabad, n.d.

Akram, Muhammad. "Beyond Dichotomies: The Import of Gadamer's Hermeneutics for the Debate of Relationship between Theology and Religious Studies." Islamic Studies 52 (June 2013): 137-53.

Akramullah, Hamdan. "Aspek-Aspek NeoModernisme Fazlur Rahman Dan Kontribusinya Bagi Epistimologi Islam." Universitas Gadjah mada, 2002.

Al-Saji, Alia, and Brian Schroeder. "Introduction." The Journal of Speculative Philosophy 30, no. 3 (January 2016): 235-41. https://doi.org/10.5325/jspecphil.30.3.0235

Amal, Taufik Adnan. Islam Dan Tantangan Modernitas. Bandung: Mizan, 1990.

Amirpur, Katajun. "New Islamic Thinking in Islam: The Jihad for Democracy." Review of Middle East Studies 51, no. 1 (February 8, 2017): $77-79$ https://doi.org/10.1017/rms.2017.1.

Bakhtiar, Amsal. Filsafat Agama 1. Ciputat: Logos Wacana Ilmu, 1997.

Buijs, Martijn. "Theology, Ontotheology, and Eschatology in Schelling's Late Thought." The Journal of Speculative Philosopby 30, no. 3 (2016): https://doi.org/10.5325/jspecphil.30.3.0373

Chittick, William C. Science of the Cosmos, Science of the Soul: The Pertinence of Islamic Cosmology in the Modern World. Oxford: Oneworld Publication, 2007.

Evans, C. Stephen. "God's Command. By John E. Hare." The Journal of Theological Studies, October 2016, flw158. 
https://doi.org/10.1093/jts/flw158.

Genequand, Charles. "Metaphysics," in History of Islamic Philosophy. Edited by Seyyed Hossein Nasr and Oliver Leaman. London: Routledge, 1996. https://doi.org/10.4324/9781003070733.

Hanafi, Hasan. Dari Akidah Ke Revolusi. Edited by Dkk terj. Asep Usman Ismail. Jakarta: Paramadina, 2003.

Hosu, Ramona. "God's Word Among Hermeneutics, Exegesis and Homiletics." Journal for the Study of Religions and Ideologies 16, no. 48 (January 2017): 141-46.

Husein, Fatimah. Fazlur Rabman's Islamic Philosophy. Thesis Mas. Montreal: McGill University, 1997.

Kars, Aydogan. "Two Modes of Unsaying in the Early Thirteenth Century Islamic Lands: Theorizing Apophasis through Maimonides and Ibn "Arabî." International Journal for Philosopby of Religion 74, no. 3 (December 2013): 261-78. https://doi.org/10.1007/s11153-012-93812.

Kartanegara, Mulyadhi. Lentera Kebidupan: Panduan Memahami Tuban, Alam Dan Manusia. Bandung: Mizan Pustaka, 2016.

Loudovikos, Nikolaos. "Being and Essence Revisited: Reciprocal Logoi and Energies in Maximus the Confessor and Thomas Aquinas, and the Genesis of the SelfReferring Subject." Revista Portuguesa de Filosofia 72, no. 1 (January 2016): 117-46. http://www.jstor.org/stable/43816277.

Ma'arif, Ahmad Syafi'i. "Noe-Modernisme Dan Islam Di Indonesia: Mempertimbangkan Pemikiran Fazlur Rahman." In Peta Bumi Intelektual Islam Indonesia, edited by Ahmad Syafi'i Ma'arif. Bandung: Mizan, 1994.

Madjid, Nurcholish. "Fazlur Rahman Dan Rekonstruksi Al-Qur'an, Dalam Islamika.' Islamika, no. 2 (1993): 23-28.

Malaka, Tan. Madilog: Materialisme, Dialektika, Dan
Logika. Jakarta: Pusat Indikator, 1999.

Mas`adi, Ghufron A. Pemikiran Fazlur Rabman Tentang Metodologi Pembaruan Hukum Islam. Jakarta: RajaGrafindo Persada, 1997.

Murata, Sachiko. The Tao of Islam: Kitab Rujukan Tentang Relasi Gender Dalam Kosmologi Dan Teologi Islam. Bandung: Mizan, 1998.

Nicholson, Rynold A. Gagasan Personalitas Dalam Sufisme Terj. A. Shibabulmillah. Yogyakarta: Pustaka Sufi, 2002.

Raharjo, Dawam. Islam Dan Masyarakat: Pandangan Fazlur Rahman," Dalam Intelektual Intelegensia Dan Perilaku Politik Bangsa. Dawam Raha. Bandung: Mizan, 1993.

Rahman, Fazlur. Islam. Chicago: The University of Chicago Press, 1979.

. Islam and Modernity: Transformation of an Intellectual Tradition. Chicago: The University of Chicago Press, 1982.

. Islamic Methodology in History. Central Institute of Islamic Research, 1965.

- Major Themes of the Qur'an. Chicago: University of Chicago Press, 1989.

The Philosophy of Mulla Sadra. New York: State University of New York Press Albany, 1975.

Tafsir, Ahmad. Filsafat Umum: Akal Dan Hati Sejak Thales Sampai Capra. Bandung: PT Remaja Rosdakarya, 2000.

Welz, Claudia. "Difficulties in Defining the Concept of God: Kierkegaard in Dialogue with Levinas, Buber, and Rosenzweig." International Journal for Philosophy of Religion 80, no. 1 (August 2016): 61-83. https://doi.org/10.1007/s11153-015-9544$z$. 